\title{
Cinegeo
}

International Journal of Environment and Geoinformatics (IJEGEO) is an international, multidisciplinary, peer reviewed, open access journal.

\section{Construction of a GIS-based database as a platform for the financial management of land in Quat Lam Town of Nam Dinh Province, Vietnam}

\section{Pham Quy GIANG}

\author{
Chief in Editor \\ Prof. Dr. Cem Gazioğlu \\ Co-Editors \\ Prof. Dr. Dursun Zafer Şeker, Prof. Dr. Şinasi Kaya, \\ Prof. Dr. Ayşegül Tanık and Assist. Prof. Dr. Volkan Demir
}

\section{Editorial Committee (December 2020)}

Assos. Prof. Dr. Abdullah Aksu (TR), Assit. Prof. Dr. Uğur Algancı (TR), Prof. Dr. Bedri Alpar (TR), Prof. Dr. Levent Bat (TR), Prof. Dr. Paul Bates (UK), İrşad Bayırhan (TR), Prof. Dr. Bülent Bayram (TR), Prof. Dr. Luis M. Botana (ES), Prof. Dr. Nuray Çağlar (TR), Prof. Dr. Sukanta Dash (IN), Dr. Soofia T. Elias (UK), Prof. Dr. A. Evren Erginal (TR), Assoc. Prof. Dr. Cüneyt Erenoğlu (TR), Dr. Dieter Fritsch (DE), Prof. Dr. Çiğdem Göksel (TR), Prof.Dr. Lena Halounova (CZ), Prof. Dr. Manik Kalubarme (IN), Dr. Hakan Kaya (TR), Assist. Prof. Dr. Serkan Kükrer (TR), Assoc. Prof. Dr. Maged Marghany (MY), Prof. Dr. Michael Meadows (ZA), Prof. Dr. Nebiye Musaoğlu (TR), Prof. Dr. Masafumi Nakagawa (JP), Prof. Dr. Hasan Özdemir (TR), Prof. Dr. Chryssy Potsiou (GR), Prof. Dr. Erol Sarı (TR), Prof. Dr. Maria Paradiso (IT), Prof. Dr. Petros Patias (GR), Prof. Dr. Elif Sertel (TR), Prof. Dr. Nüket Sivri (TR), Prof. Dr. Füsun Balık Şanlı (TR), Prof. Dr. Uğur Şanlı (TR), Duygu Ülker (TR), Prof. Dr. Seyfettin Taş (TR), Assoc. Prof. Dr. Ömer Suat Taşkın (US), Assist. Prof. Dr. Tuba Ünsal (US), Dr. İnese Varna (LV), Dr. Petra Visser (NL), Prof. Dr. Selma Ünlü (TR), Prof. Dr. Murat Yakar (TR), Assit. Prof. Dr. Sibel Zeki (TR) 
Reaserch Article

\title{
Construction of a GIS-based database as a platform for the financial management of land in Quat Lam Town of Nam Dinh Province, Vietnam
}

\author{
Pham Quy Giang \\ Faculty of Environment, Ha Long University, Quang Ninh, VIETNAM
}

E-mail: phamquygiang@daihochalong.edu.vn

Received: 10 April 2020

Accepted: 28 June 2020

How to cite: Giang, PQ. (2020). Construction of a GIS-based database as a platform for the financial management of land in Quat Lam Town of Nam Dinh Province, Vietnam, .International Journal of Environment and Geoinformatics (IJEGEO), 7(3):228-238. DOI: 10.30897/ijegeo.717832

\begin{abstract}
In recent years, as a result of urbanization and the development of tourism and services, land market in Vietnam has been blooming. The bloom of the land market has made land management in general and financial management of land in particular become more important than ever. Based on GIS technology, the present study has built a database of land with full details of each land parcel in order to support the financial management of land in Quat Lam, a coastal tourist town in Nam Dinh Province. The database also provides land users and managers with sufficient information on transportation, hydrology and service systems, which influence the land price. The database allows land managers to carry out financial management related tasks such as: Searching for land parcel information; calculation of registration fees, calculation of income tax from the transfer of land use rights, compensation for ground clearance upon land acquisition; search of land parcels according to financial capability; development of specialized thematic maps regarding land prices, financial obligations and legal status of the land. The established database is practically valuable for land managers as well as land users as it facilitates the process of change updates, data analysis, processing and sharing, and consequently improving the efficiency in the financial management of land.
\end{abstract}

Keywords: Database, GIS, Financial Management of Land, Land parcel, Land price

\section{Introduction}

The land is always considered one of the most valuable resources, sustainable use and management of land is therefore extremely important in the development strategy of each country. Nowadays, with the increasing demand of land use and the vibrant development of the land market, the volume of data to be managed and analyzed will increase, and this will require more and more application of modern technologies which provide short processing time and high accuracy analyses. Since its inception in the early 1960s, Geographic Information System (GIS) has been being widely used in natural resources and environmental management from global scale to national scale and local scale (Skidmore, 2002; Pham et al., 2012; Xie et al., 2015; Ülker et al., 2018; Lawal, 2020). In recent years, with the rapid development of science and technology, GIS has made great improvements with stronger capacity in data integration, analysis and visualization, and has become the main tool to support natural resource management in general and land management in particular (Pham et al., 2011), and as such, the application of GIS in land management is very well documented (Abbas and Arigbede, 2011; Nyongesa, 2012; Nguyen et al., 2015; Valdez et al., 2019; Beta et al., 2019; Gebremariam et al., 2020).

In recent years, in Vietnam, land, especially land price, has been becoming a hot issue, attracting the attention of many different sectors in society. The Land Law, together with the decrees and circulars issued, has made land management and land use more and more effective. In particular, financial management of land is always important content to be mentioned. In the current Land Law of Vietnam (Land Law 2013), financial management is one of the fifteen contents of the State management over land, together with other essential contents which include managing master plans and plans on land use; managing land allocation, land lease, land recovery and change of land use purposes; managing compensation, support and resettlement upon land recovery (The National Assembly, 2013). However, because most of the local management authorities, especially in the district and communal levels, still strongly rely on traditional management methods which are based on paper documents, land management in the general and financial management of land, in particular, are facing difficulties. Even in the localities where modern technologies like GIS, GPS (Global Positioning System) and Remote Sensing have been applied, the land information system is still incomplete and inconsistent (Tran et al., 2019). This situation has made challenges when performing land management tasks such as landuse change update, the search of information to each land parcel and each land user, determination of financial obligations for land use or land use right transfer, determination of compensation money for land clearance and land acquisition.

The main aim of the present study was, therefore, to apply the advantages of GIS in land management, 
particularly in the financial management of land based on a GIS-created land database. Quat Lam, a coastal tourist town in Nam Dinh Province, which represents a vibrant land market and is in critical need of a GIS-based land management system, was selected as a case study. The database established and its applications are practically valuable for land managers as well as land users as it facilitates the process of information searching, land-use change updates, data analysis, processing and sharing, and consequently improving the efficiency in the financial management of land in the study area.

\section{Materials and method Materials and software}

In the present study, data from a variety of sources were collected in order to establish the database for financial management of land in Quat Lam Town. Secondary data including data of natural and socio-economic conditions, land use data, State-regulated land price and specific land price, land use maps, cadastral maps, and other cadastral documents (including land inventory books, cadastral books, log-books of land use right certificates issuance, monitoring books of land-use changes, etc.) were obtained from government agencies from the town level to the provincial level. A survey was carried out in order to investigate the actual changes which have not been updated in the collected cadastral maps. Data on market land price was collected through a questionnaire interview with local people and authorities.
In order to analyze and process input data for the construction of spatial data and attribute data of the database, MicroStation and ArcGIS software were employed.

\section{Methods}

The cadastral map system of Quat Lam Town consists of 36 maps drawn in 2004, all built at the scale of 1:1000. The maps were edited in MicroStation software and exported to Shapefiles, which is the data format of ArcGIS software. ArcGIS was then employed for the construction of the database. First, the spatial data was set with Spatial Reference in ArcGIS. A spatial reference is the georeferencing and coordinate system assigned to the data (ESRI, 2019). The spatial data were divided into four layers, including the layer of land parcels, the layer of the transportation system, the layer of the hydrological system, and the layer of the service system. Each layer was then constructed with appropriate attribute fields to store all information necessary for the financial management of land and other related land management tasks. Based on the traditional spatial and attribute databases, several applications were deployed in order to perform land management tasks using functions of ArcGIS such as searching and analyzing data, land price mapping, calculating financial levies of land users. A flowchart of methodology of the present study is shown in Figure 1.

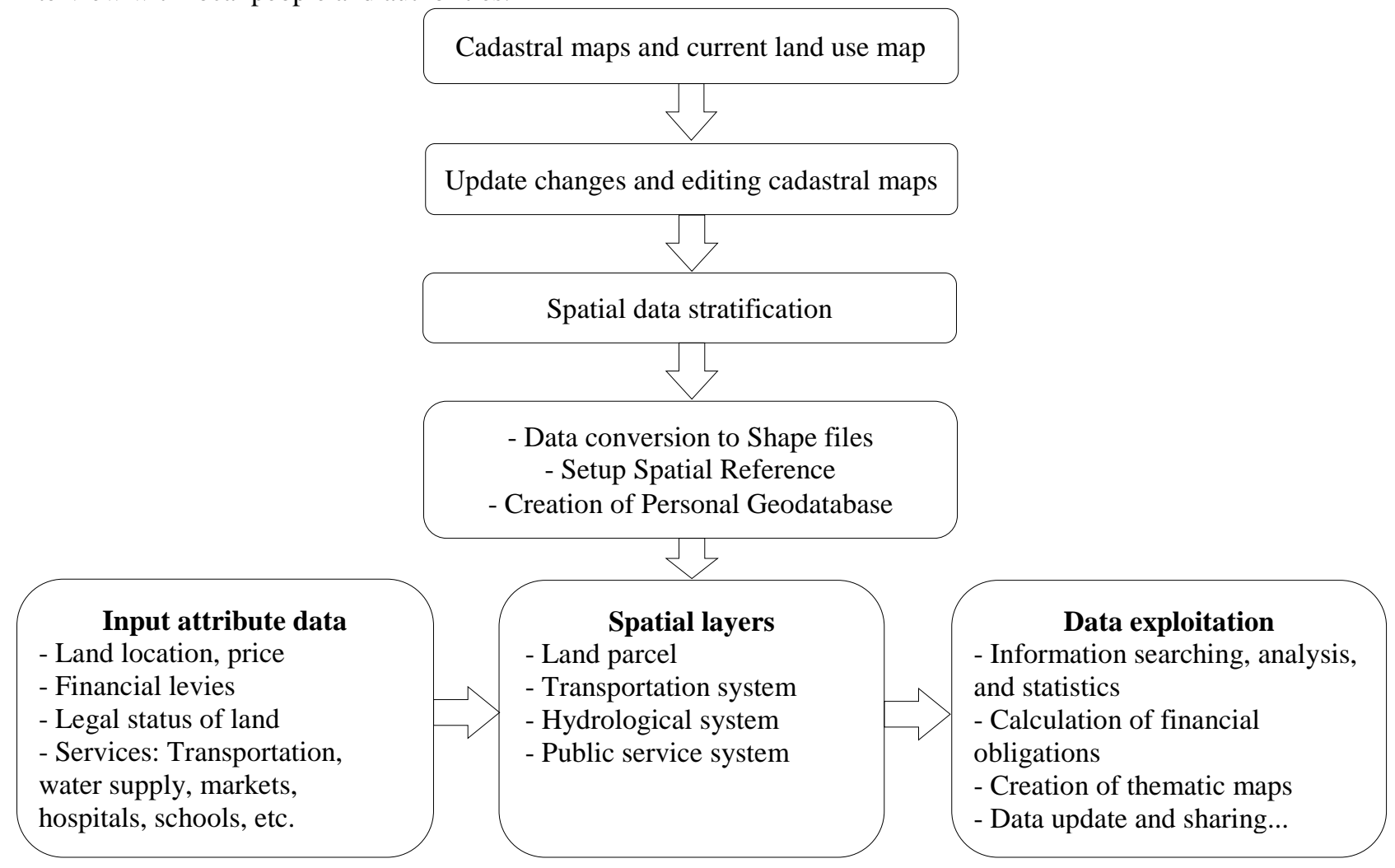

Fig. 1. Flowchart of construction and exploitation of the land database 


\section{The study area}

Quat Lam is a coastal tourist town located southwest of Giao Thuy district, $45 \mathrm{~km}$ from Nam Dinh City along with provincial road number 482 and national road number 21. The town covers an area of 791.3 hectares and has a population of approximate 10,000 people (a population density of over 1,260 people/ km2) (Statistical Office of Giao Thuy District, 2019). The geographic location of the study area is shown in Figure 2. Quat Lam is the cultural, economic and political centre of the southwestern residential area of Giao Thuy district due to its flat terrain, fertile soil, mild climate, favourable geographical position, creating conditions for exchange and development. The town attracts investment from the province and the central government, especially in the field of tourism - services (Quat Lam Town People's Committee, 2019). With the development of tourism in recent years, the real estate market in the town has been becoming exciting. The rapid growth of the land market has made financial management of land more important than ever.

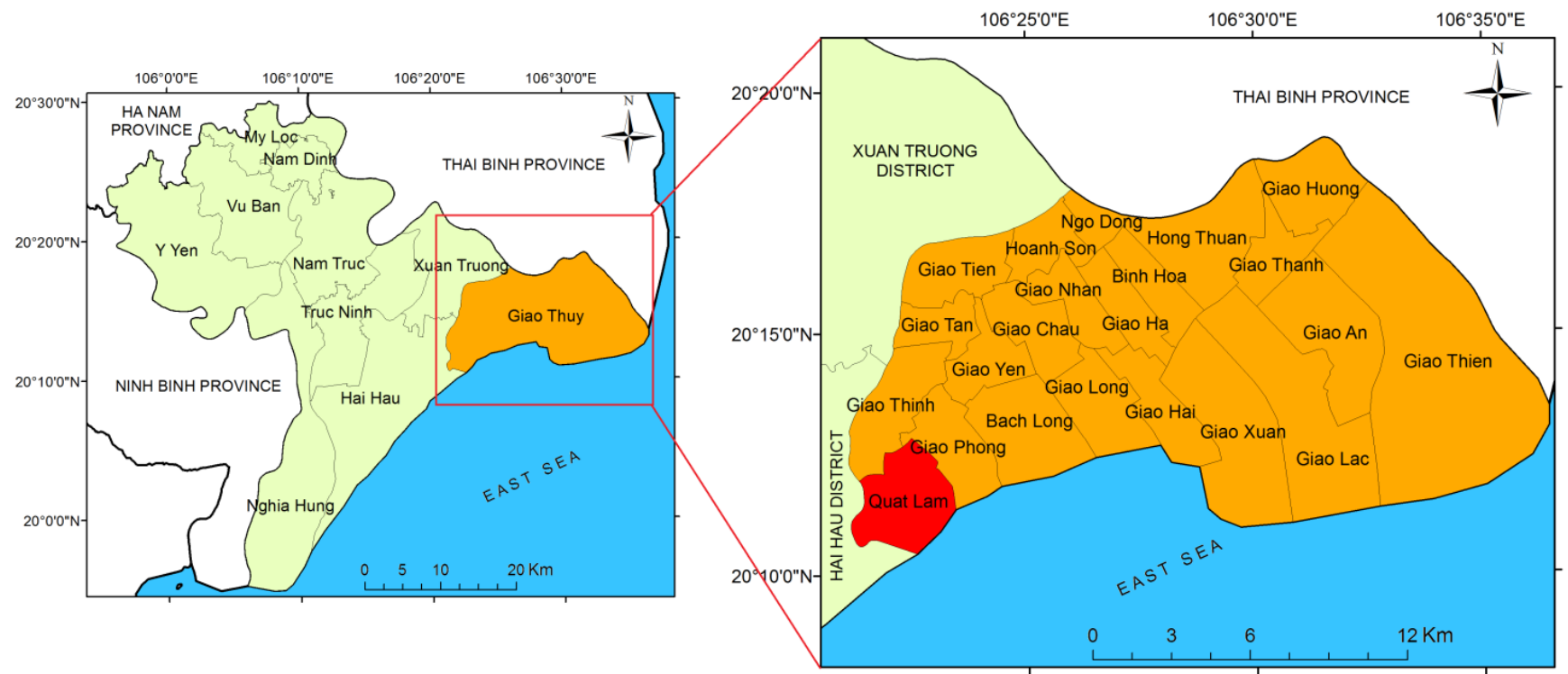

Fig. 2. Location of Quat Lam Town in Nam Dinh Province.

\section{Results and Discussion The database}

The established database consists of four layers, including the layer of land parcels, the layer of the transportation system, the layer of the hydrological system, and the layer of service system. Of the four layers, the layer of land parcels is the primary layer comprises all information of each land parcel necessary for financial management. This information was transferred from different documents including cadastral maps, current land use map of 2019, cadastral logbooks, land-use change logbooks, land use right certificate issuance logbooks, and decision on the land price. The attribute database includes fields on different aspects such as basic information of the land parcel (map number, parcel number, location, and area), legal status (land use owner, land use purpose, land use right certificate, and land use term), the value of land (Stateregulated land price, specific land price, and market land price) and financial obligation (land registration fee, annual land-use tax, and tax of land use right transfer). Each data field was constructed with an appropriate data type and precision. In this paper, the spatial data and attribute data for the cadastral map number 12 are selected for presentation. The database is shown in Figure 3, while the structure of attribute data fields of the land parcel layer is shown in Table 1.

The other three layers were built in order to provide supporting information on the factors influencing land price and useful for the financial management of land. The Transportation System layer provides information on the road system including name, width, length, type, and level of roads. The Hydrological System layer provides information on all water bodies and drainage system including name, width, length, depth, area, and water quality. Meanwhile, the Service System layer is a point-type layer providing information on the system of markets, schools, hospitals and clinics, religious places, and other public service points. 


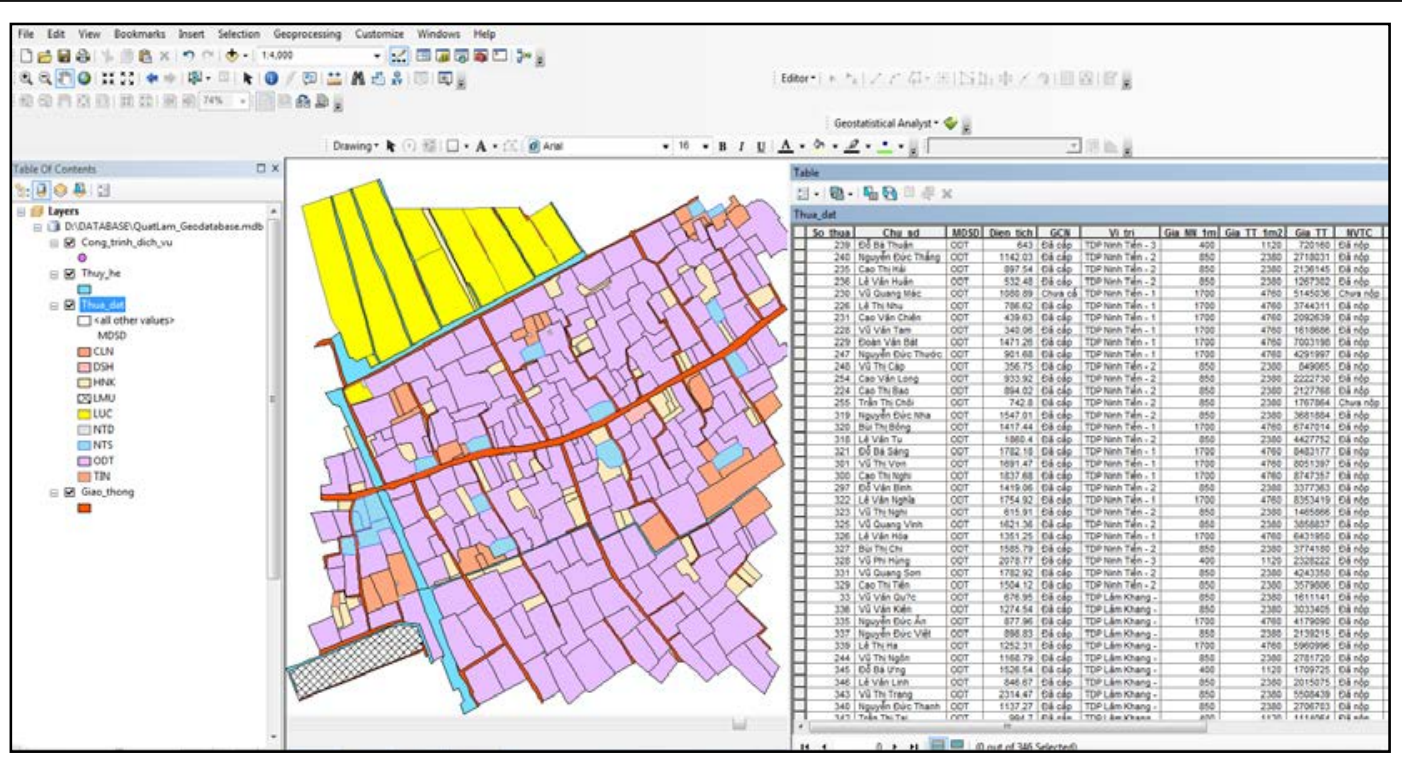

Fig. 3. Spatial data and attribute table of the Land Parcel Layer

Table 1. Structure of attribute data fields of the Land Parcel Layer

\begin{tabular}{|c|c|c|c|c|c|}
\hline No & Field Name & Field Type & $\begin{array}{c}\text { Field } \\
\text { Length }\end{array}$ & Unit & Description \\
\hline 1 & So_to & Short Interger & 3 & N/A & Cadastral map number \\
\hline 2 & So_thua & Short Interger & 5 & N/A & Land parcel number on the cadastral map \\
\hline 3 & Diachi_thuadat & Text & 50 & N/A & Address of the land parcel \\
\hline 4 & Chu_sd & Text & 30 & N/A & Name of the land user \\
\hline 5 & Dia_chi_csd & Text & 50 & N/A & Address of the land user \\
\hline 6 & MST_chu_sd & Text & 13 & N/A & Tax identification number of the land user \\
\hline 7 & MDSD & Text & 3 & N/A & Abbreviation of current land use purpose \\
\hline 8 & Thoi_han_sd & Text & 20 & N/A & Term (duration) of land use \\
\hline 9 & Nguon_goc_sdd & Text & 50 & N/A & Origin of land use \\
\hline 10 & Hinh_thuc_sd & Text & 20 & N/A & Type of land use (share or independent) \\
\hline 11 & Han_che_qsdd & Text & 50 & N/A & Limitations on land use right \\
\hline 12 & Dien_tich & Float & $10(2)$ & $\mathrm{m}^{2}$ & Area of the land parcel \\
\hline 13 & Taisan_gan_lien & Text & 50 & N/A & Assets attached to land \\
\hline 14 & GCN & Text & 10 & N/A & Land use right certificate possession \\
\hline 15 & Vi_tri & Text & 30 & N/A & Location of the land parcel \\
\hline 16 & Gia_NN_1m² & Float & $10(1)$ & 1000.VND & State regulated land price (per m²) \\
\hline 17 & Gia_NN & Float & $15(1)$ & 1000.VND & $\begin{array}{l}\text { Total value of the land parcel according to the State } \\
\text { regulated land price }\end{array}$ \\
\hline 18 & Gia_Cuthe & Float & $10(1)$ & 1000.VND & $\begin{array}{l}\text { The specific land price per } \mathrm{m}^{2} \text { determined by } \\
\text { Provincial People's committee }\end{array}$ \\
\hline 19 & Gia_TT_1m² & Float & $10(1)$ & 1000.VND & Market price of land (per $\mathrm{m}^{2}$ ) \\
\hline 20 & Gia_TT & Float & $15(1)$ & 1000.VND & $\begin{array}{l}\text { Total value of the land parcel according to the market } \\
\text { land price }\end{array}$ \\
\hline 21 & NVTC & Text & 15 & N/A & Status of the fulfillment of financial obligations \\
\hline 22 & No_TSDD & Text & 10 & N/A & Debt of land use levy (yes/no) \\
\hline 23 & LPTB & Float & $10(1)$ & 1000.VND & Land registration fee \\
\hline 24 & Thue_CQSDD & Float & $10(1)$ & 1000.VND & Tax of land use right transfer \\
\hline 25 & Ghi_chu & Text & 50 & N/A & Other notes \\
\hline
\end{tabular}




\section{Application of the database in the financial management of land Information searching}

Using the utilities for information searching of ArcGIS, the authorities can search and inventory plots of land those satisfy one or more conditions at the same time.

Example 1: Search for the land parcels that owe land use fee.

In order to implement this task, "Select by Attributes" function was used as shown in Figure 4. The result shows that there are 17 land parcels of which the land use fee has not been paid to the tax authority.

Example 2: Search for the urban residential land parcels facing the inter-communal road and having market price lower than 3 billion VND (note that the unit for the field Gia_TT (market price) has been set as 1,000 VND as in Table 1). To implement this task, the inter-communal road (the main road in the study area) from the Transportation System layer was selected using the "Select by Attribute" function, and the "Select by Location" function was then use to find the land parcels those touch the boundary of this road. Finally, from the parcels which have been found, the "Select by Attribute" function was used again to find the parcels which have land use purpose as urban residential land (abbreviated as "ODT" in Vietnamese) and having market price equal or lower than 3 billion VND. The result shows that 28 parcels satisfied the search conditions. The process to implement this task is shown in Figure 5.

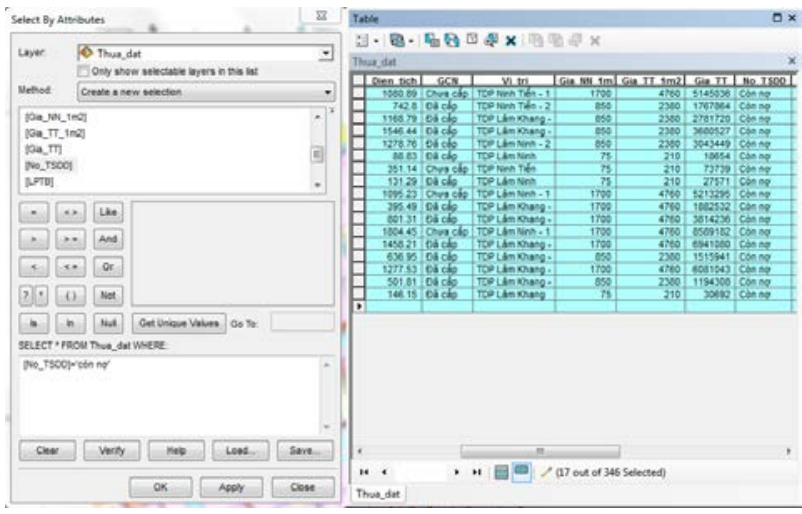

Fig. 4. The result of searching for land parcels of which land use fee has not been paid

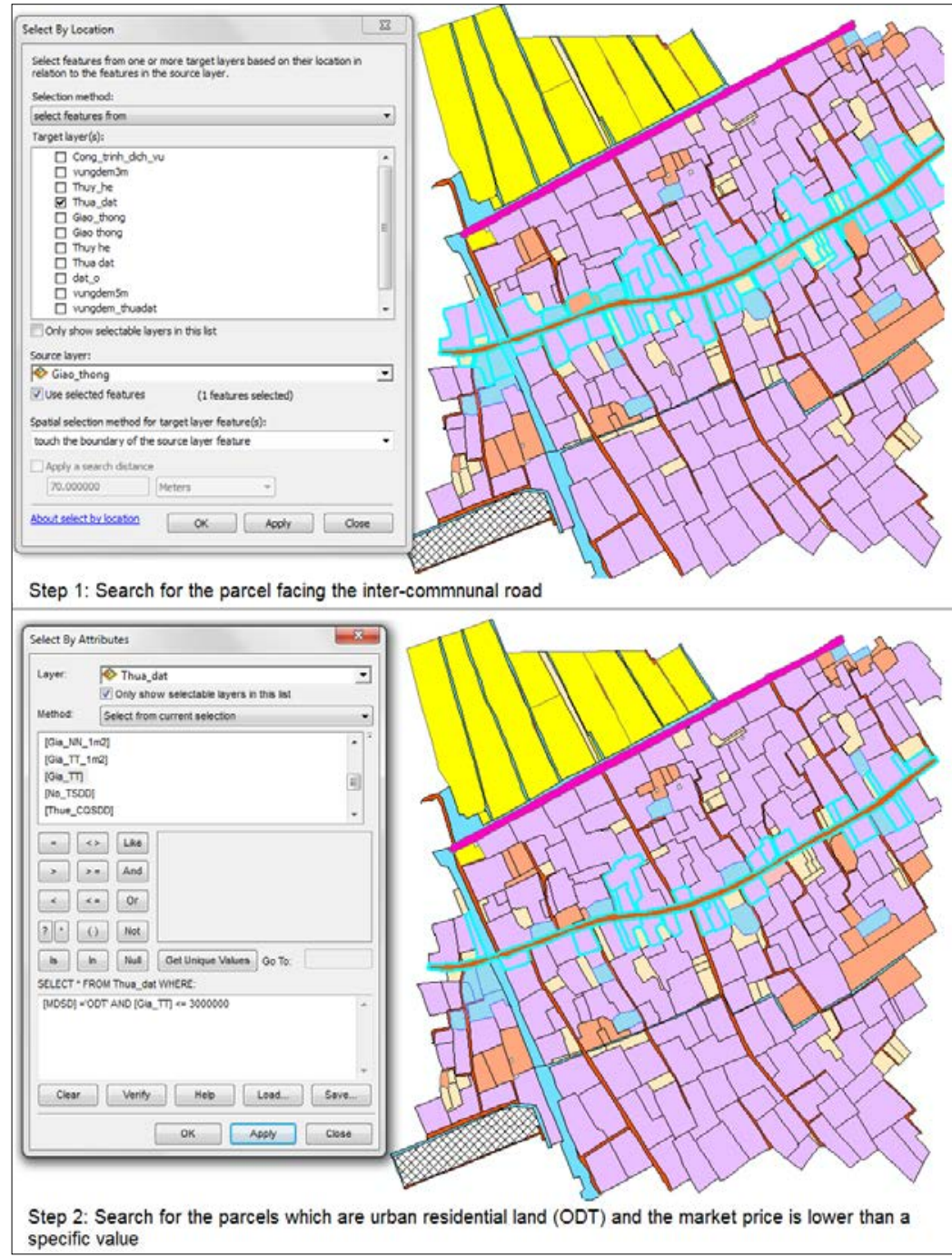

Fig. 5. Process of searching for the land parcel satisfies the financial capacity. 


\section{Calculation of land registration fee}

Based on the established land database, calculation of land registration fee to be paid for each parcel of land (upon receipt of the certificate of land use right or transfer of land use right) can be implemented with a few simple commands. Building the database on ArcGIS ensures accuracy and accelerates the process to transfer the fee to the tax authorities. According to the State's regulation, the registration fee of a land parcel is charged by 0.5 per cent of the total value of the land parcel according to the State-regulated land price, in other words:

Registration fee $=0.005 *$ State-regulated land price per $\mathrm{m}^{2} *$ Land area

The calculation method and calculation results of the registration fee are shown in Figure 6.

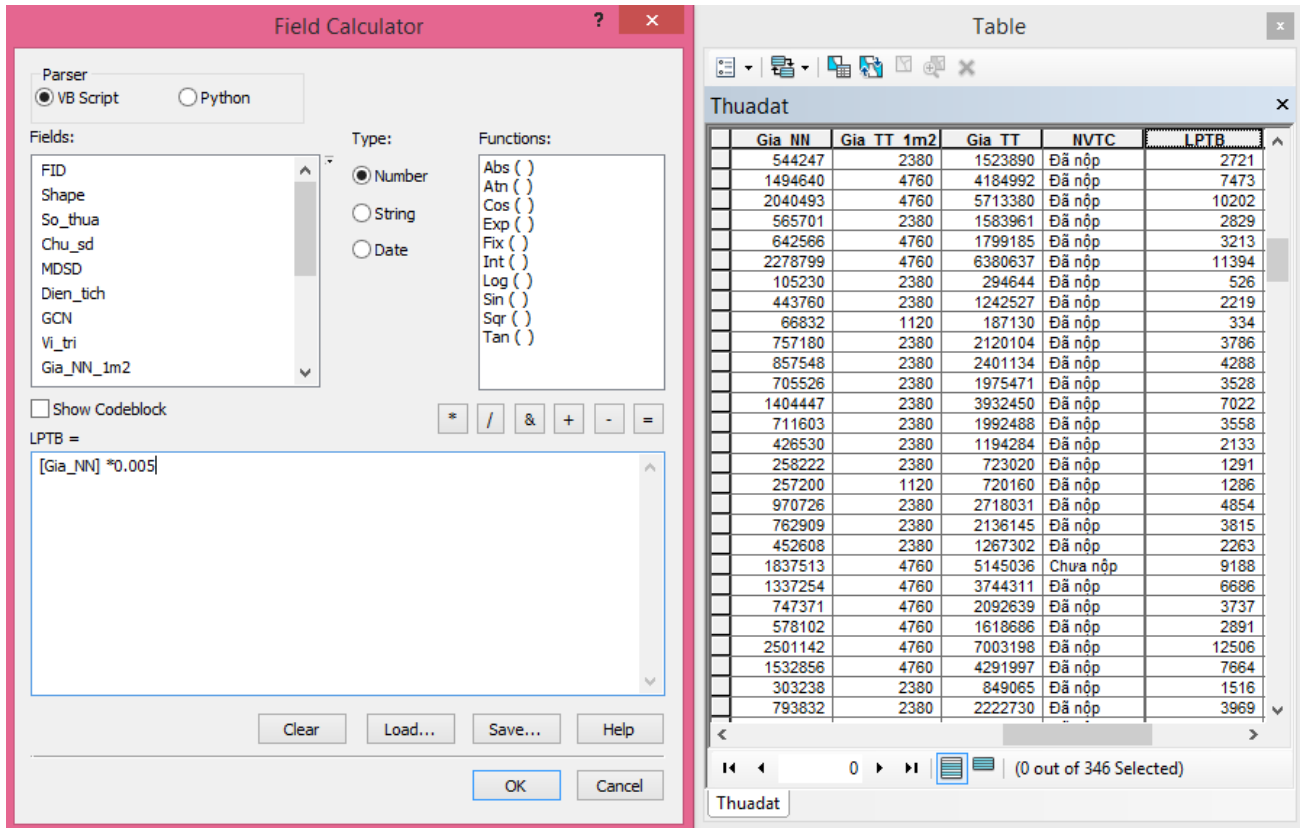

Fig. 6. Calculation method and the calculated registration fee (LPTB field)

\section{Calculation of personal income tax from land use right transfer}

Personal income tax on the transfer of land use rights is a tax on the convert or transfer of land use rights to others as prescribed by law. This type of income tax is calculated as follows:

Case 1: The land transfer price is larger than the State regulated land price:

Personal income tax $=2 \% *$ Land transfer price per $\mathrm{m}^{2} *$ Land area

Case 2: The land transfer price is smaller than the Stateregulated land price:

Personal income tax $=2 \% *$ State-regulated land price per $\mathrm{m}^{2} *$ Land area

These calculations can be done in ArcGIS's Field Calculator function.

\section{Calculation of annual land use tax}

According to the State's regulations, organizations, households and individuals using residential land must pay annual land use tax. In order to calculate the land use tax for each parcel of land, the following formula is applied in ArcGIS's Field Calculator:
Annual tax of residential land $=$ Taxable price ${ }^{*}$ Tax rate (\%)

where taxable price $=$ Land price per $m^{2} *$ Land area $\left(m^{2}\right)$

\section{Calculation of compensation money for land clearance} and land acquisition

Vietnam is in the process of accelerating industrialization, modernization and urbanization, the number of investment projects and development of infrastructure projects such as hi-tech parks, industrial parks, industrial village clusters, urban areas, transportation planned is increasing. In order to implement these projects, it is necessary to use large areas of land and land acquisition, land clearance will undoubtedly have to be done, and the most concerning issue is the compensation for land acquisition. The established database helps financial administrators of land with rapid calculation methods based on ArcGIS software.

Example: Calculation the area of land loss and compensation for people losing land when the government implements a road expansion project that expands a road by 3 meters each side of the road. The calculation of land loss and compensation amounts is made as follows: (1) Create a buffer zone with a distance of 3 meters. This step will generate a new layer 
("Vungdem3m"). (2) Overlaying the layer "Vungdem3m" and the layer of the land parcel ("Thuadat"). A new layer ("Vungdem_thuadat") will be created. (3) In this new layer, create two new fields for storing data of land area to be cleared and compensation amount to be paid for land owners. The area of land loss can be calculated automatically using the "Calculate Geometry" function of ArcGIS, while the compensation amount is determined by the State as follows:

Compensation amount $=$ Specific land price per $m^{2} *$
Where "Specific land price" is the price determined by the Provincial People's Committee based on the investigation, collection of information about land parcels, market land price and information on land price in the land database, and based on suitable valuation methods (The National Assembly, 2013).

The expanded road (in pink colour), area of land loss, and the compensation amount in this example are shown in Figure 7.

Land area

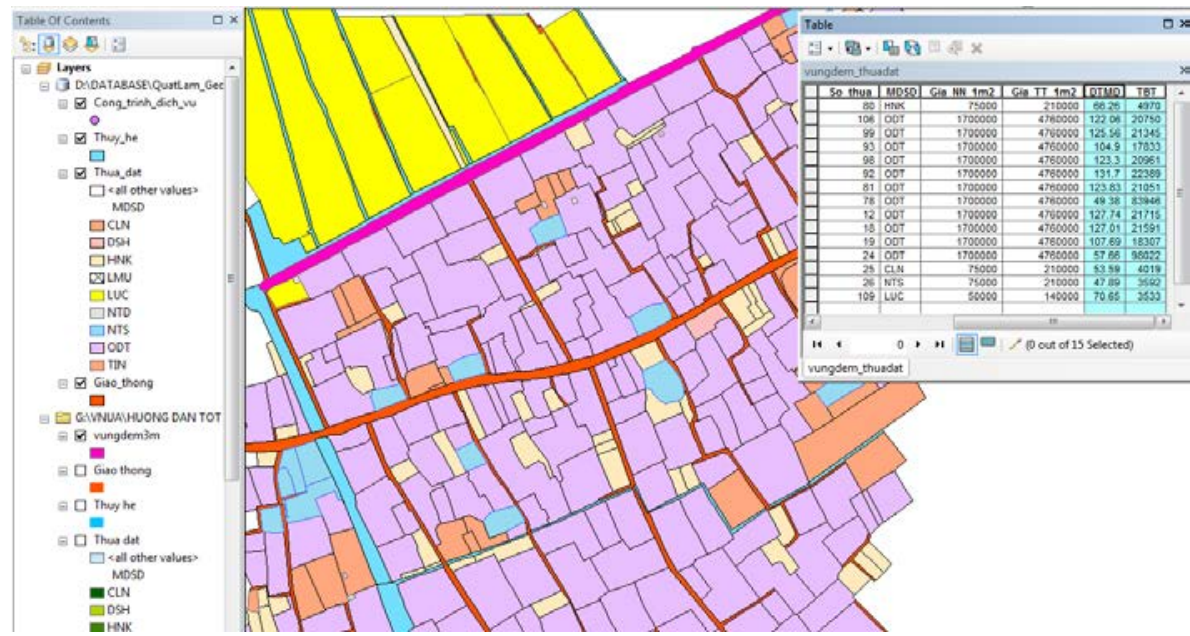

Fig. 7. The expanded road (in pink colour), area of land loss and the compensation amount

After the calculation, statistics of the total number of affected land plots, the total land loss area, and the total compensation amount can be implemented using the Statistics tool of ArcGIS. The results of the statistics are presented in Figure 8. The results show that if the competent agency implements the project to expand the route, it will affect 15 land parcels, taking a total land area of $1439.22 \mathrm{~m}^{2}$, including perennial cropland (CLN), annual cropland (HNK), paddy land (LUC), aquaculture land (NTS), and urban residential land (ODT). The total compensation amount is estimated at more than 2 billion VND.

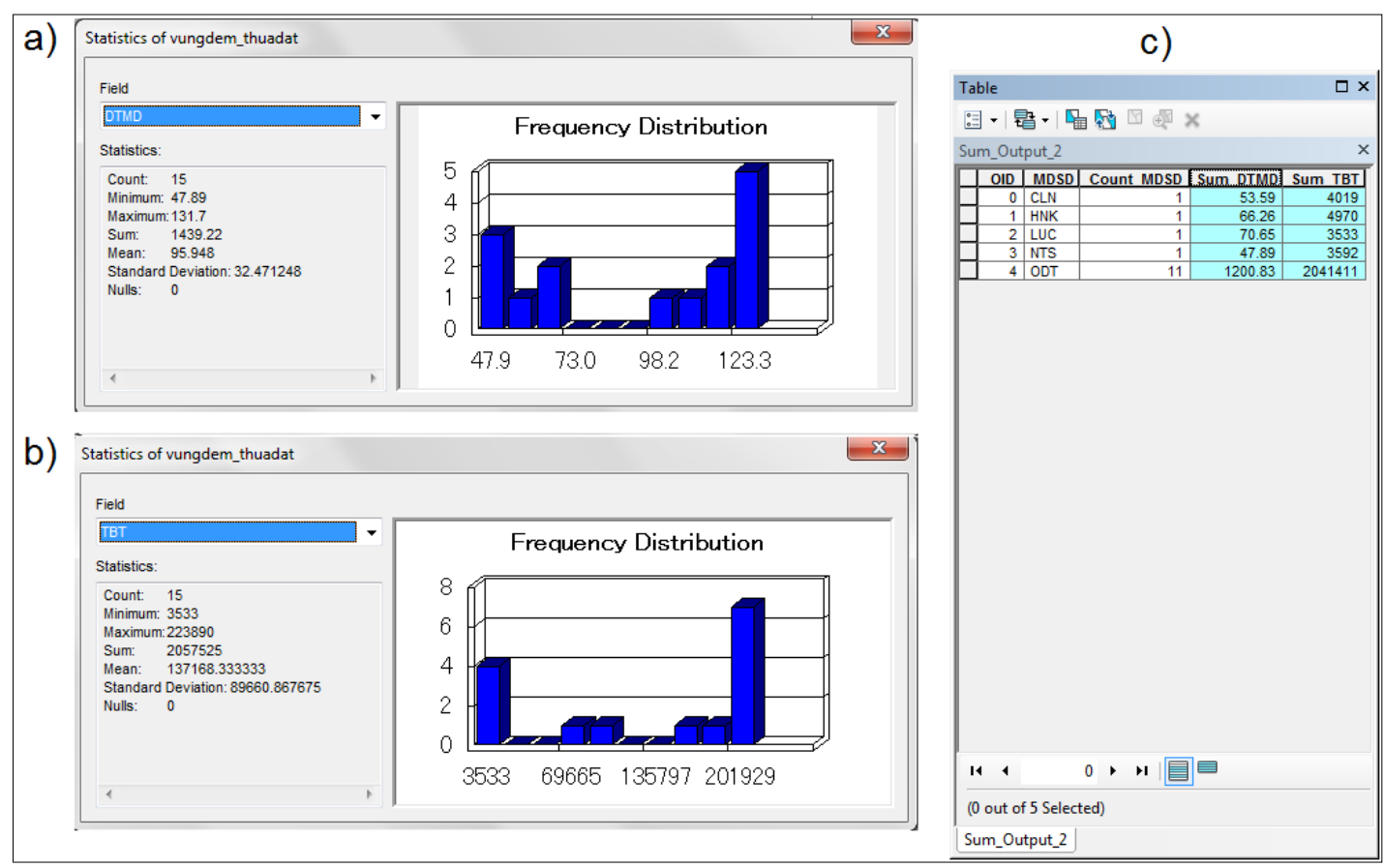

Fig. 8. (a) Statistics of land clearance area due to road expansion, (b) the compensation amount, and (c) summary for each land use type. 


\section{Thematic map generating}

Based on the established database, a number of thematic maps which are useful for financial management of land such as map of land parcel location, map of market land price, and map of land parcel value can be generated using functions of ArcGIS. With the software, these thematic maps can be presented as a Choropleth Map, Graduated Symbol Map, Dot Map, Isopleth Map, Cartograms, Dasymetric Map, Chart or Diagram, etc (Zatelli, 2009; Grayson, 2010; ESRI, 2019). These thematic maps provide land managers and user with a very effective way to visualize and present information. Figure 9 and Figure 10 respectively present thematic map of land parcel location and land price. The location of the land parcel shown in Figure 9 is determined based on Decision No. 32/2014/QD-UBND dated December 30, 2014 of Nam Dinh Provincial People's Committee promulgating regulations on prices of different types of land in Nam Dinh Province applied from 01/01/2015 to 31/12/2019 (Nam Dinh Provincial People's Committee, 2014). Meanwhile, the land price (unit in VND) shown in Figure 10 is for each land parcel calculated from the area of each land parcel and the State regulated land price per square meter.

\section{Conclusion and recommendation}

In this study, a spatial database and an accompanied attribute database of land for Quat Lam Town of Nam
Dinh Province were constructed from cadastral maps and other input data sources. The databases provide land users and managers with full details of each land parcel and supporting information including the transportation, hydrology, and service systems in the area.

The exploitation of the database for the financial management of land makes it convenient for the management agencies and land users to carry out tasks such as: Searching for land parcel information, calculation of land registration fees and annual land-use tax, calculation of income tax from the transfer of land use rights, calculation of compensation for ground clearance upon land acquisition, the search of land plots according to financial capacity, and development of specialized thematic maps regarding land prices, financial obligations and legal status of the land.

The established database has met the requirements of calculating and searching information, facilitating the process of change updates as well as saving time, improving the efficiency in the financial management of land. It is therefore recommended that the application of GIS in the financial management of land should always be made as one of the first priorities in the improvement and modernization of the land management system.

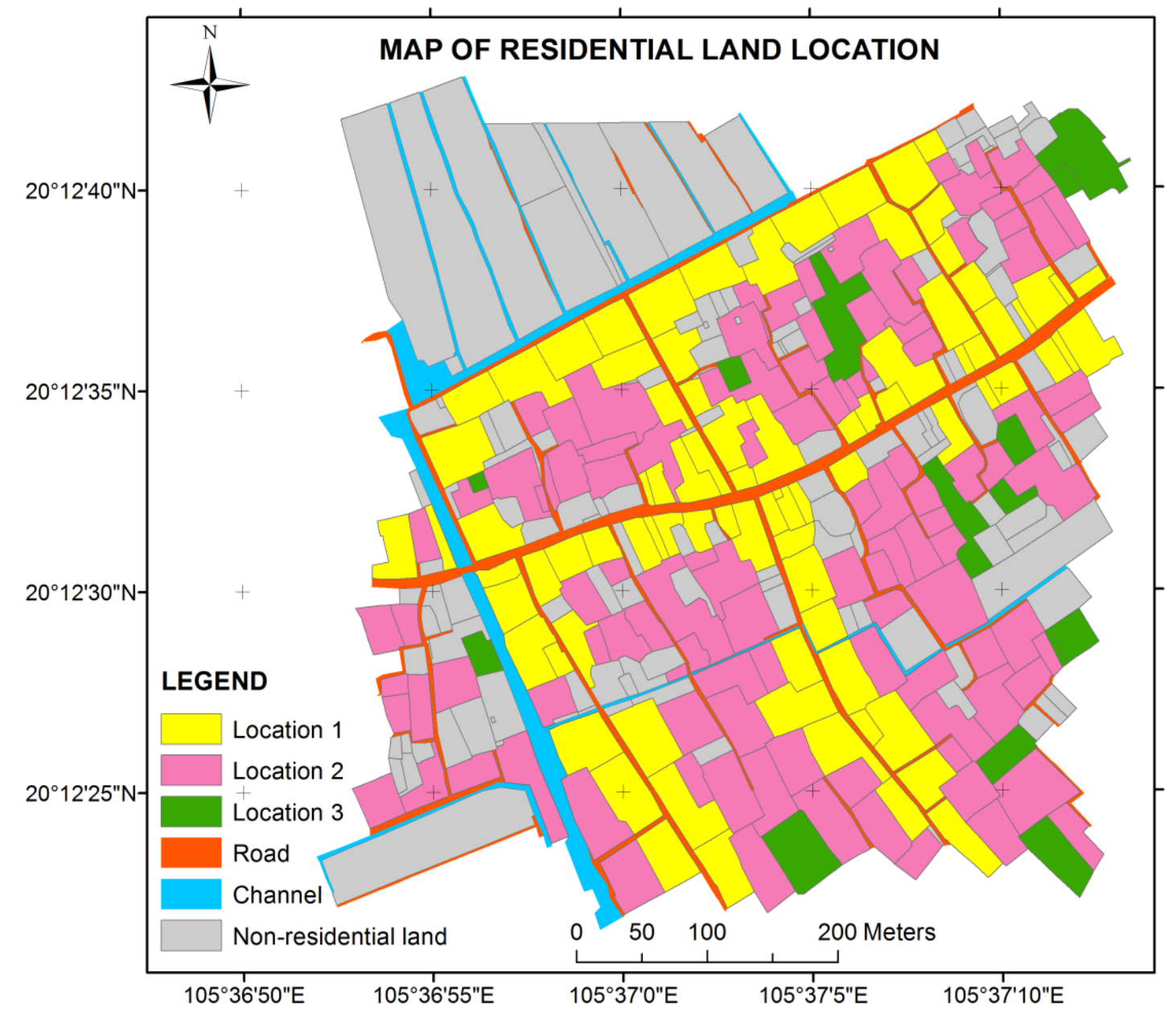

Fig. 9. Thematic map of residential land location 


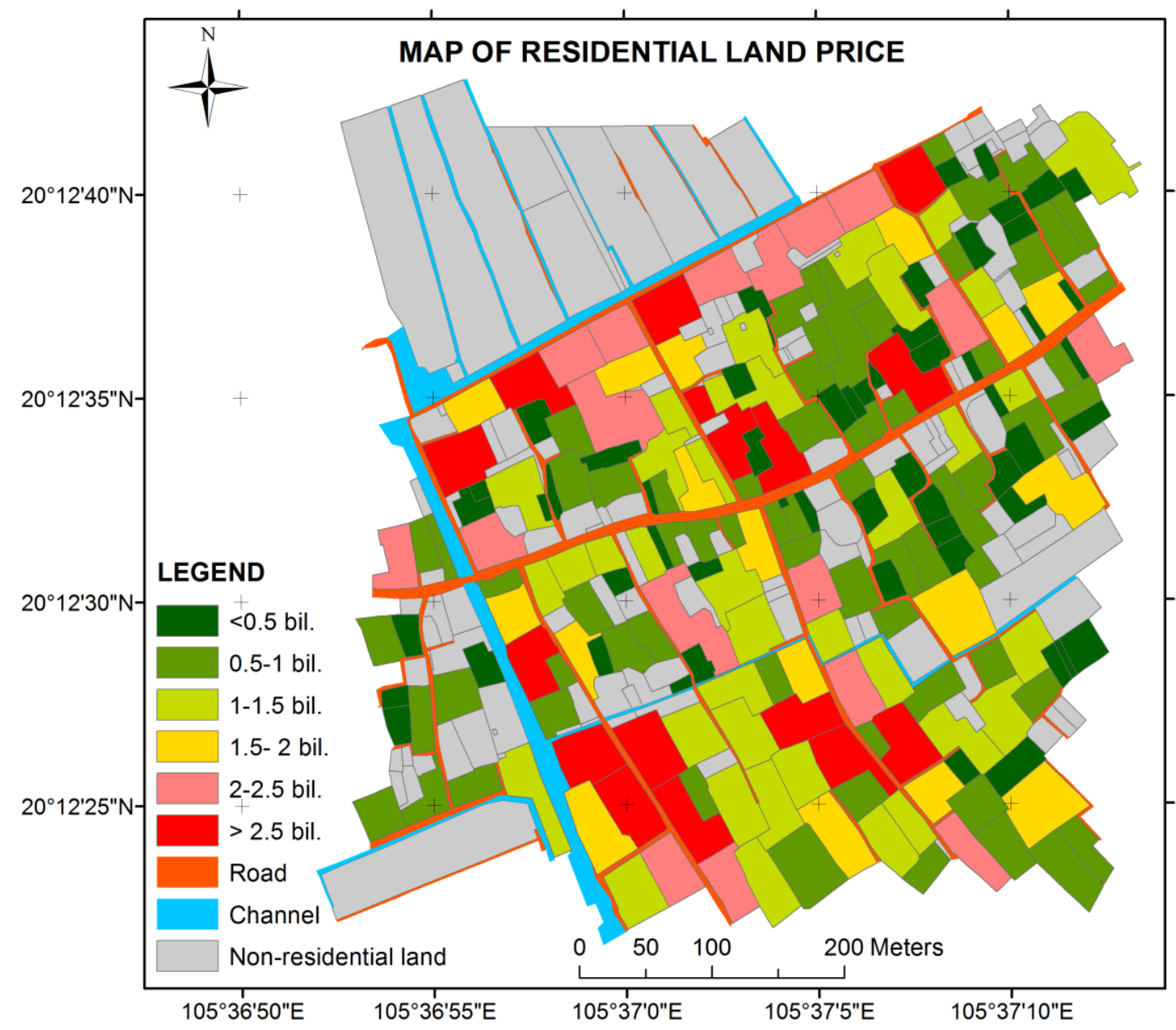

Fig. 10. Thematic map of residential land price.

\section{Acknowledgements}

The author appreciates the anonymous reviewers for their valuable comments and suggestions for the improvement of the manuscript.

\section{References}

Abbas, I.I., Arigbede, Y.A. (2011). Sustainable land management in Zaria using Remote Sensing and GIS techniques. Journal of Ecology and the Natural Environment, 3(4), 131-138.

Bera, K., Banik, P. (2019). Geoinformatics based MicroWatershed wise Land capability analysis for Sustainable Land Resources Management. Research \& Reviews: Journal of Ecology, 8(1), 39-46.

ESRI. (2019). Advanced thematic mapping. ESRI documentation. The Environmental Systems Research Institute, California, USA.

ESRI. (2019). Introduction to Spatial References. ESRI documentation. The Environmental Systems Research Institute, California, USA.

Gebremariam, F., Habtu, S., Adane, Y., Gebreegziabher, T., Solomon, N., Yazew, E. (2020). Investigating the Reliability of Irrigated Area Coverages from Fragmented Lands: The case of Tigray, Northern Ethiopia. International Journal of Environment and Geoinformatics, 7(2), 172-183. DOI: 10.30897/ijegeo.655595.
Grayson, T.H., Kang, M., Chung, J., Zhao, J., Liao, X., Diao, M., Chen, Y., Zhu, Y. (2010). Lab Exercise 2: Thematic Mapping in ArcMap. A Workshop on Geographic Information Systems, Department of Urban Studies and Planning, Massachusetts Institute of Technology. Cambridge, Massachusetts, USA.

Lawal, O. (2020). Spatially Constrained Clustering of Nigerian States: Perspective from Social, Economic and Demographic Attributes. International Journal of Environment and Geoinformatics, 7(1) , 68-79 . DOI: $10.30897 /$ ijegeo.588032.

Nam Dinh Provincial People's Committee. (2014). Decision No. 32/2014/QD-UBNDdated December 30, 2014 of Nam Dinh People's Committee promulgating regulations on prices of different types of land in Nam DinhProvince applied from 01/01/2015 to 31/12/2019.

Nguyen, T.T, Verdoodt, A., Van, Y.T.,et al. (2015). Design of a GIS and multi-criteria based land evaluation procedure for sustainable land-use planning at the regional level. Agriculture, Ecosystems \& Environment, 200, 1-11.

Nyongesa, L.N. (2012). Gis-based National Land Information Management System (NLIMS).Paper presented at FIG Working Week 2012: Knowing to manage the territory, protect the environment, evaluate the cultural heritage. Rome, Italy, May 610, 2012.

Pham Q.G., Nakhapakorn, K., Ussawarujikulchai,A. (2011). Effectiveness of different spatial interpolators 
in estimating heavy metal contamination in shallow groundwater: A case study of arsenic contamination in Hanoi, Vietnam. Environment and Natural Resources Journal, 9 (1), 31 - 37.

Pham,Q.G., Kunikane, S., Toshiki, K., Sakata, M. (2012). Investigating and mapping spatial patterns of arsenic contamination in groundwater using regression analysis and Spline interpolation technique. Journal of Water Supply Research and Technology AQUA. 62 (6), 385 - 394.

Quat Lam Town People's Committee. (2019). Report of Socioeconomics development of 2019. Quat Lam, Giao Thuy, Nam Dinh, Vietnam.

Skidmore, A. (2002). Environmental modelling with GIS and remote sensing. London: Taylor and Francis.

Statistical Office of Giao Thuy District. (2019). Statistical year book 2019 of Giao Thuy District. Giao Thuy, Nam Dinh, Vietnam.

The National Assembly. (2013). Vietnam Land Law 2013 - Law No. 45/2013/QH13. Labour Publishing House, Hanoi, 2013.

Tran, Q.V., Chu, D.V., Pham, Q.G. (2019). Application of Remote Sensing and GIS to establish a rice-land database for the protection of the national heritage area of terraced fields in Hoang Su Phi District, Ha Giang Province. Journal of Agriculture and Rural Development (in Vietnamese), 359 (2), 136-142.

Ülker, D., Ergüven, O., Gazioğlu, C. (2018). Socioeconomic impacts in a Changing Climate: Case Study Syria. International Journal of Environment and Geoinformatics, 5(1), 84-93. DOI: 10.30897/ijegeo.406273.

Valdez, M., Chen, C.F., Chiang, S.H., Chang, K.T.,, Lin, Y.W., Chen, Y.F., Chou, Y.C. (2019).Illegal land use change assessment using GIS and remote sensing to support sustainable land management strategies in Taiwan. Geocarto International, 34 (2), 2019.

Xie, H., Yao, G., Liu, G. (2015). Spatial evaluation of the ecological importance based on GIS for environmental management: A case study in Xingguo County of China. Ecological Indicator, 51, 3-12.

Zatelli, P. (2009). Thematic maps. Department of Civil, Environmental and Mechanical Engineering, University of Trento, Italy. 